\title{
THE ANGLE OF ELECTRICAL CARDIAC AXIS IN TRAINED THOROUGHBRED RACE HORSES
}

\author{
J. HANÁK \\ Department of Diagnostics, Therapy and Prophylaxis, \\ University of Veterinary Science, 61242 Brno \\ Dedicated to the 50th birthday of Prof. MVDr. P. Jagoš CSc. \\ Received February 11, 1980
}

\begin{abstract}
Hanák J.: The Angle of Electrical Cardiac Axis in Trained Thoroughbred Race Horses. Acta vet. Brno, 49, 1980: 205-210.

The influence of training on the angle of electrical cardiac axis in 5 planes of tetrahedron was followed on 226 thoroughbred horses divided into three experimental groups.

It was found that the training of horses does not induce statistically significant changes in angle of electrical cardiac axis. Some of the changes which occur during long and short distance training can be accounted for by bilateral heart hypertrophy. The predominating hypertrophy of left ventricle is manifested by deviation of electric axis towards right and horizontally, that of right ventricle by deviation of electric axis to the left and horizontally.
\end{abstract}

Horse, heart, electrical axis, training.

The overall weight of heart as well as the size of its individual ventricles are the factors determining the heart shape, its location and the angle of anatomical cardiac axis. It is well known that there are significant variations of this value not only in different species and in different individuals within one species but there are also even intraindividual variations. These differences are due to the effect of external and internal factors which influence first of all the weight of heart and mutual ratio of ventricular size. In this respect mainly physiological or pathological ventricular hypertrophy is most frequently occurring.

Although the anatomical cardiac axis is not identical with electrical axis the cardiac morphological changes are reflected also upon the angle of electrical cardiac axis. As reported e.g. by Deegen and Matthiesen (1977) a pronounced left deviation of electrical cardiac axis $\left(-46^{\circ}\right)$ in newborn foals is due to more vertical position of heart and righthand ventricular hypertrophy. During a few months of life left ventricular hypertrophy becomes to develop and the electric axis is rotating clockwise in horizontal plane (Deegen and Matthiesen 1977; Hanák 1979, 1980 a, b). The angle of electrical cardiac axis in the saggital plane changes from the semivertical to semihorizontal position (Hanák 1979, $1980 \mathrm{a}, \mathrm{b}$ ). The rotation of electrical axis from left to right as well as caudohorizontally as a consequence of foal growth is determined first of all by the increasing cardiac size and by so called growth left ventricular hypertrophy which changes the position of heart in the rib cage.

Hypertrophy of the ventricles caused by cardiac disorders is also reflected upon the angle of electric axis. According to observations of White and Rhode (1974) valvulopathy in left heart (aortal and mitral disorders) and hindrances in systemic blood circulation accompanying other extracardial diseases may induce left hypertrophy and a shift of electrical cardiac axis towards right in a horizontal plane $\left(\alpha>60^{\circ}\right)$. Valvulopathy of the right heart (pulmonary and tricuspidal) as well as hypertension in pulmonary blood circulation (during pneumonia, emphysema, hemo- 
phlegia laryngis etc.) lead to right hypertrophy and a change of angle of electrical cardiac axis towards left $\left(\alpha<30^{\circ}\right)$.

Other authors reported on changes of electrical cardiac axis direction during pregnancy of mares starting from 7th month (Holmes and Alps 1967) or those induced by changing altitude (Gross and Alu ja 1970). Also during overall illness or a local disorder certain changes of electrical cardiac axis have been noted as reported e.g. by Wh ite and Rode (1974). The angle of electrical cardiac axis is also determined by certain genetic conditions (H anák and Žert 1980).

It was the purpose of this work to examine the influence of long-lasting training of thoroughbred race horses upon the electrical cardiac axis angle.

\section{Materials and Methods}

The influence of training on the angle of electrical cardiac axis in horizontal $(\mathrm{H})$, transveral (T), saggital-right ( $\mathrm{Sr}$ ), saggital-left (Sl) and saggital-medium $(\mathrm{Sm})$ plane has been followed on 226 thoroughbreds. ECG records were made on a STARTEST (Chirana) instrument using the tetrahedron lead system (Hanák 1979; Hanák and Jagoš 1980).

Heart beats in all cases examined were clear, well defined with no additional murmurs or arrhythmias. The horses taken for examination exhibited no clinical symptoms of illness; they were fed normally and had been trained regularly from the age of 20 months. According to the duration of training process the animals were divided into three experimental groups:

First experimental group was represented by 20 horses of both sexes whose cardiac electrical axis angle was measured at the age of 17-20 months (so-called yearlings) prior to the transfer to the training centre. The value was measured again after 1 year of training (2-year old) and after 2 years of training (3-year old).

In the second experimental group there were 48 two-year-old horses (trained for one year), 58 three-year-old horses (trained for two years) and 40 horses four and more years old (trained for three years and more).

The third experimental group consisted of 40 horses at the age of 17-20 months (yearlings) just before their departure to training centre, $\mathbf{4 0}$ horses after three and more years lasting training ( 4 and more years old) taken from the second experimental set and 20 thoroughbred mares whose racing career finished three years ago and had been since kept for breeding, not being trained.

The obtained results were statistically treated and tabulated. To determine the statistical significance of training on the electrical cardiac axis angle a method of simple variance analysis was used together with the Duncan test.

\section{Results}

Changes in electrical cardiac axis angle during the two years lasting training observed in the first experimental group are presented in Table 1. It shows that in the $\mathrm{H}$ plane a gradual increase in angle occurs accompanied by rotation of electrical cardiac axis from left to right (from $54.38^{\circ}$ to $59.10^{\circ}$ ). On the other hand in all saggital planes $(\mathrm{Sr}, \mathrm{Sl}, \mathrm{Sm})$ the value of angle gradually decreases and electrical cardiac axis assumes more horizontal position. Only in the $T$ plane the angle is first slightly increasing (after 1 year of training) and then decreases again. The mentioned changes are, however, statistically non-significant $(P>0.05)$.

Table 1

Angle of electrical cardiac axis measured on 20 horses (1st experimental group) during two years of training

\begin{tabular}{|c|c|c|c|}
\hline Plane & Prior to training & After 1 year of training & After 2 years of training \\
\hline H & $45.38 \pm 28.23$ & $57.50 \pm 30.12$ & $59.10 \pm 14.66$ \\
T & $62.18 \pm 15.65$ & $65.20 \pm 19.25$ & $61.40 \pm 16.19$ \\
Sr & $50.70 \pm 18.65$ & $44.42 \pm 22.83$ & $34.60 \pm 19.80$ \\
S1 & $63.29 \pm 18.20$ & $57.05 \pm 28.31$ & $48.65 \pm 19.54$ \\
Sm & $55.26 \pm 17.81$ & $50.80 \pm 22.17$ & $41.63 \pm 15.70$ \\
\hline
\end{tabular}


Table 2

Angle of electrical cardiac axis measured on three age categories of trained race horses (2nd experimental group)

\begin{tabular}{|c|c|c|c|}
\hline Plane & $\begin{array}{l}2 \text { years old } \\
(n=48)\end{array}$ & $\begin{array}{l}3 \text { years old } \\
(\mathrm{n}=58)\end{array}$ & $\begin{array}{l}4 \text { years old and older } \\
\qquad(\mathrm{n}=40)\end{array}$ \\
\hline $\begin{array}{l}\mathbf{H} \\
\mathbf{T} \\
\mathbf{S} \mathbf{r} \\
\mathbf{S} \mathbf{I} \\
\mathbf{S m}\end{array}$ & $\begin{array}{l}60.50 \pm 31.50 \\
64.20 \pm 20.50 \\
46.80 \pm 22.63 \\
59.05 \pm 26.30 \\
51.60 \pm 22.80\end{array}$ & $\begin{array}{l}59.80 \pm 16.50 \\
62.30 \pm 17.83 \\
38.60 \pm 20.10 \\
49.65 \pm 19.56 \\
43.63 \pm 16.70\end{array}$ & $\begin{array}{l}57.95 \pm 15.40 \\
63.25 \pm 11.21 \\
38.68 \pm 18.63 \\
49.80 \pm 20.00 \\
45.00 \pm 16.67\end{array}$ \\
\hline
\end{tabular}

Also in the second experimental set there were notable changes in the angle of electrical cardiac axis depending on the age group or on the duration of training process (Table 2). In all tetrahedron planes more or less pronounced lowering of the angle of electrical cardiac axis could be seen to occur. In the $\mathrm{H}$ plane the electrical axis rotated slightly towards left. In saggital planes ( $\mathrm{Sr}, \mathrm{Sl}, \mathrm{Sm})$ the electrical cardiac axis assumes more vertical position in the group of 2-year and 4-year-old horses than in the case og 3-year-old animals. A similar situation was in the $\mathrm{T}$ plane. All these changes are, however, not statistically significant $(P>0.05)$.

Table 3

Angle of electrical cardiac axis in non-trained, trained and de-trained horses (3rd experimental group)

\begin{tabular}{|c|c|c|c|}
\hline Plane & $\begin{array}{c}\text { Non-trained } \\
(\mathrm{n}=40)\end{array}$ & $\begin{array}{c}\text { Trained } \\
(\mathrm{n}=40)\end{array}$ & $\begin{array}{c}\text { De-trained } \\
(\mathrm{n}=20)\end{array}$ \\
\hline $\mathrm{H}$ & $45.75 \pm 25.19$ & $57.95 \pm 14.50$ & \\
$\mathrm{~T}$ & $62.17 \pm 14.56$ & $63.25 \pm 11.21$ & $54.85 \pm 21.24$ \\
$\mathrm{Sr}_{\mathrm{S}}$ & $49.05 \pm 17.83$ & $39.68 \pm 18.63$ & $62.90 \pm 16.43$ \\
$\mathrm{Sm}$ & $62.78 \pm 22.39$ & $49.80 \pm 20.00$ & $45.80 \pm 21.06$ \\
& $54.90 \pm 18.48$ & $45.00 \pm 16.67$ & $42.85 \pm 17.85$ \\
\hline
\end{tabular}

The influence of training and de-training on the angle of electrical cardiac axis in the third experimental group is summarized in Table 3. The statistical analysis of tabulated values has shown that there are not statistically significant differences in the angle of electrical cardiac axis for nontrained 17-20 months old horses and trained race horses. Neither there were differences between the former and de-trained breeding mares when measuring the angle of electrical cardiac axis in $\mathrm{H}, \mathrm{T}, \mathrm{Sr}$ and $\mathrm{Sm}$ planes $(P>0.05)$. The only significant difference in the angle of electrical cardiac axis was noted in the $S 1$ plane for the group of non-trained yearlings and trained race horses $(P<0.05)$. In this plane there was also a highly significant difference between the group of non-trained yearlings and de-trained breeding mares $(P<0.01)$. The group of trained horses and de-trained breeding mares has statistically more pronounced horizontal position of electrical cardiac axis in the S1 plane than the group of non-trained yearlings. In other tetrahedron planes there are, however, not significant differences in the angle of electrical cardiac axis as far as trained horses and de-trained breeding mares are concerned $(P>0.05)$. 


\section{Discussion}

The most pronounced rotation of electrical cardiac axis in horses is due to the body growth and to one-sided so-called growth hypertrophy of the left heart (Deegen and Matthiesen 1977; Hanák 1979, 1980a,b). Starting from the age of 13-15 months, bilateral hypertrophy is developing and the electrical cardiac axis no longer exhibits significant rotation (Hanák 1980a). According to our previous observation (Hanák 1979) and according to the present work, training has no statistically significant influence on the angle of electrical cardiac axis.

During two years of training period there were no significant changes in electrical cardiac axis in the case of first experimental group. These were characterized by the right directed horizontal rotation. Also in the second experimental set the changes in direction of electrical cardiac axis were non-significant. Electrical axis was inclined more leftward than in the case of younger age categories of horses. The only significant influence of a long lasting training ( 3 and more years) upon the rotation of the electrical cardiac axis was noted in the Sl plane where the movement was directed horizontally when compared with non-trained yearlings (see 3rd experimental group). During the de-training the angle of electrical cardiac axis is no longer changed, this being the reason for a significant difference in the angle of electric cardiac axis of the long-trained horses as well as breeding mares and that of nontrained yearlings. These differences between long-trained horses and de-trained breeding mares on one hand and non-trained yearling on the other hand may, however, be due to a substantial age differences between these categories.

The non-significant influence of training upon the angle of electrical cardiac axis indicates that the position of heart in the rib cage is no longer changed which was not the case during one-side cardiac hypertrophy observed in foals (Hanák $1979,1970 \mathrm{a}, \mathrm{b})$. It is well-known, however, that so-called induced cardiac hypertrophy may develop upon training (Herrmann 1929). It is, however, bilateral hypertrophy which occurs on both right and left ventricle (Kubo et al. 1974) not influencing the angle of electrical cardiac axis (Hanák 1979).

The deviation of electrical cardiac axis towards right, and in horizontal direction, which was observed during the two-year training period in 1st experimental group may be accounted for by predominating hypertrophy of left ventricle during this period. A more pronounced left hypertrophy causes the rotation of both anatomical and electrical axis towards right and horizontally. It is manifested by the increasing angle of electrical cardiac axis in the $\mathrm{H}$ plane and decreasing the angle in saggital axes, namely in the Sr plane. This conclusion is corroborated by the fact that race horses in this age category ( 2 and partially 3 years old) are exploited predominantly for short distances. The energetical coverage in so-called speedtraining and during flyer race is provided on account of oxygen. This exploitation represents much higher functional demands upon systemic circulation and left heart than upon pulmonary circulation and right heart. This creates conditions for predominating hypertrophy of left ventricle.

An opposite tendency in the second experimental set (left rotation) can be explained by significant hypertrophy of right ventricle occurring in older categories of horses. Right-hand hypertrophy can never predominate over the left one. It causes the rotation of anatomical and electrical cardiac axis towards left. It is manifested by the decreasing of electrical cardiac axis in $\mathrm{H}$ and $\mathrm{Sl}$ planes and on the other hand by the increasing angle in other planes. This is further 
confirmed by the fact that horses older than 3 years are exploited mostly for longer distance runs and those older than 4 years mostly for endurance steeple-chase. The energetical coverage of so called endurance training is mostly on account of aerobic route. This increases the functional demands not only on systemic circulation and left heart but also on pulmonary blood circulation and right heart. Myocardium of the right ventricle then becomes hypertrophic more easily than during the speed exploitation.

These findings were further corroborated in the 3rd experimental set. The significant rotation of electrical cardiac axis in a horizontal direction in S1 plane in long-trained horses and in de-trained horses when compared with non-trained yearlings signifies also a pronounced contribution of right ventricular hypertrophy in training-induced bilateral cardiac hypertrophy.

These conclusions may seem speculative but they are deduced from the vector interpretation of one-sided hypertrophy based on the electrical cardiac axis in tetrahedron space. They may be compared only with similar observations of changes of electrical cardiac axis, accompanying pathological one-side hypertrophy induced by cardiac disorders (White and Rhode 1974; Mill and Hanák 1978) or by growth hypertrophy of left heart (Deegen and Matthiesen 1977; Hanák 1979, 1980a). Pathological one-side hypertrophy of right or left heart causes, however, extremely pronounced changes in angle of electrical cardiac axis towards left or right, vertically or horizontally (White and Rhode 1974, Mill and Hanák 1978).

Our results concerning one-side predominance in bilateral training-induced cardiac hypertrophy observed under physiological conditions cannot, however, be compared with the results of other authors since this topic has not been previously studied. It will be necessary to carry out vectorcardiographic analysis also for the case of so called flyers (i.e. short distance runners efficient at distances up to $1600 \mathrm{~m}$ ) and in long-trained horses prepared for endurance runs such as Grand National Pardubice Steeple-Chase. The comparison of these two groups of specialists might disclose the role of anaerobic and aerobic metabolic exploitation on the development of left or right training-induced cardiac hypertrophy.

\section{Conclusion}

The training of race horses does not induce statistically significant changes in angle of electrical cardiac axis. Some of the changes which occur during long and short distance training can be accounted for by predominating left ventricular hypertrophy (deviation of axis towards right in the $\mathrm{H}$ plane and horizontally in the Sr plane) or by more pronounced hypertrophy of right ventricle (deviation of axis towards left in the $\mathrm{H}$ plane and vertically in Sl plane). These are connected with bilateral training-induced cardiac hypertrophy.

\section{Sklon elektrické osy srdeční u trénovaných plnokrevných dostihových koní}

U 226 plnokrevných koní, rozdělených do tří pokusných souborů, byl sledován vliv tréninku na sklon elektrické osy srdeční v 5 rovinách tetraedronu.

Bylo zjištěno, že tréninkem koní nedochází ke statisticky významným změnám 
ve sklonu elektrické osy srdeční. Některé změny, které nastávají během tréninku na krátké a dlouhé distance, jsou spojeny s bilaterální tréninkovou hypertrofií srdce. Převaha hypertrofie levé komory se projevuje odklonem elektrické osy směrem doprava a horizontálně, převaha hypertrofie pravé komory odklonem elektrické osy srdeční směrem doleva a horizontálně.

\section{Наклон электрической сердечной оси у тренированных полнокровных скакунов}

На 226 полнокровных скакунах, разделенных на три подопытных группы, проводились наблюдения за влиянием тренировки на наклон электрической оси сердечной в 5 уровнях тетраэдрона.

Было установлено, что под влиянием тренировки скакунов по отношению к әлектрической сердечной оси нет существенных изменений статистической значимости. Некоторые изменения, имеющие место в ходе тренировки на короткой и длинной дистанциях, связаны с билатеральной тренировочной гипертрофией сердца. Преобладание гипертрофии левого желудочка сердца проявляется отклонением электрической оси по направлению направо и горизонтально, преобладание гипертрофии правого желудочка сердца - отклонением электрической оси сердца налево и горизонтально.

\section{References}

DEEGEN, E. - MATTHIESEN, T.: Untersuchungen zum EKG des Fohlens. II. Entwicklung des QRS-Komplexes in den Standard-Extremitäten-Ableitungen innerhalb des ersten Lebensjahres. Zbl. Vet. Med., 24 A, 1977: 799-816.

GROSS, D. R. - ALUJA, A.S.: Electrocardiographic response to altitude change for horses. J. Am. Vet. Med. Ass., 156, 1970: 631-636.

HANÁK, J.: Elektrokardiografický svodový systém v diagnostice u plnokrevných koní. Ph. D. Thesis. Brno, 1979, $198 \mathrm{pp}$.

HANÁK, J.: Sklon elektrické osy srdeční a velikost komorového vektoru u plnokrevných hříbat. In press.

HANÁK, J.: Vliv tréninku plnokrevných hřibat na sklon elektrické osy srdeční a velikost komorového vektoru. In press.

HANÁK, J. - JAGOŠ, P.: Elektrokardiografický svodový systém a jeho vektorové ověření. In press.

HANÁK, J. - ŽERT, Z.: Některé znaky EKG plnokrevných koní společné pro rodiče a jejich potomstvo. Vet. Med., Praha, 1980, v tisku.

HERRMANN, G.: The heart of the thoroughbred race horse. Proc. Soc. Exp. Biol., New York, 26, 1929: 549-551.

HOLMES, J. R. - ALPS, B. J.: Studies into equine electrocardiography and vectorcardiography. II. Cardiac vector distributions in apparently healthy horses. Can. J. Compar. Med., 31, 1967: $150-155$.

KUBO, K. - SENTA, T. - SUGIMOTO, O.: Relationship between training and heart in thoroughbred racehorse. Exp. Rep. Eg. Hlth. Lab., 11, 1974: 87-93.

MILL, J. - HANÁK, J.: Abnorme Herzbefunde bei Vollblutrennpferden. Monatshtf. f. Veterinärmed., 33, 1978: 508-511.

WHITE, N. A. - RHODE, E. A.: Correlation of electrocardiographic findings to clinical disease in the horse. J. Am. Vet. Med. Ass., 164, 1974: 46-56. 